\title{
EFL Pre-Service Teachers' Perceptions of an Ideal English Teacher
}

\author{
Onni Annisa \& Yulia Hapsari \\ Universitas Brawijaya \\ E-mail: annisa_onni@student.ub.ac.id;hapsari.yulia@ub.ac.id
}

\begin{abstract}
How to cite (in APA Style): Annisa, O., \& Hapsari, Y. (2020). EFL pre-service teachers' perceptions of an ideal Englihs teacher. Jurnal Pendidikan Bahasa dan Sastra, Vol. 20(2), 233-242. doi:https://doi.org/10.17509/bs_jpbsp.v20i2.33063
\end{abstract}

Article history: (Received: 16 July 2020, Revised: 18 Aug 2020, Accepted: 1 Sept 2020)

Journal homepage: http://ejournal.upi.edu./index.php/BS_JPBSP

\begin{abstract}
One of the requirements standards of being a professional teacher in Indonesia is having four teacher competences; pedagogical, personality, social and professional competences. Yet, the empirical data show that Indonesian education quality and teacher competence are still below the standards, including English teacher. This concern leads curiosity about pre-service teachers' awareness of this situation. Therefore, this study was aimed to discover EFL pre-service teachers' perception on the criteria of an ideal English teacher within the framework of the four teachers' standard competences, the most important competence and their consideration in choosing it. By using explanatory sequential mixed method, 100 EFL pre-service teachers were involved. The data were gathered through a questionnaire, then followed up by an interview to some participants. As the result, a divergence finding was found. Personality competence obtained the highest mean score on the criteria of an ideal English teacher while pedagogical competence was opted as the most important competence. Further, an interview was done to reveal considerations contributing to the divergence finding. The interviewees agreed with the criteria constructing the personality competence as teachers are role model who must set good example for their students. However, teaching is teachers' main task where they need to deliver their knowledge to students in order to achieve the learning goals through pedagogical competence. This study concludes that not only pedagogical competence that mater in teaching, but teachers' personality is also crucial.
\end{abstract}

Keywords: EFL pre-service teacher; perception; ideal English teacher; teacher competence

\section{Persepsi Calon Guru EFL Terhadap Guru Bahasa Inggris Ideal}

\begin{abstract}
Abstrak: Salah satu standar untuk menjadi guru profesional di Indonesia adalah tentang empat kompetensi guru; kompetensi pedagogi, kepribadian, sosial, dan profesional. Namun, fakta menunjukan bahwa kualitas pendidikan dan kompetensi guru di Indonesia masih dibawah standar, termasuk guru Bahasa Inggris. Hal ini memunculkan rasa keingintahuan tentang kesadaran calon guru terhadap situasi ini. Maka dari itu, penelitian ini bertujuan untuk mengetahui persepsi calon guru Bahasa Inggris tentang dua hal, yaitu 1) kriteria guru bahasa Inggris yang ideal berdasarkan empat standar kompetensi guru, dan 2) kompetensi terpenting bagi guru beserta alasannya. Dengan menggunakan Explanatory sequential mixed method, 100 calon guru Bahasa Inggris terlibat dalam pengumpulan data melalui kuesioner. Beberapa dari mereka kemudian dipilih dengan pertimbangan tertentu untuk diwawancarai. Hasil yang diperoleh menunjukkan temuan yang divergence, yaitu bahwa kompetensi kepribadian memperoleh nilai rata-rata tertinggi sementara kompetensi pedagogi terpilih sebagai kompetensi terpenting. Melalui wawancara terungkap alasan yang melatarbelakangi temuan tersebut. Para peserta wawancara setuju dengan kriteria dalam kompetensi kepribadian karena guru merupakan seorang panutan yang harus memberikan contoh yang baik terhadap muridnya. Namun, mengajar adalah tugas utama guru dimana kompetensi pedagogi sangat diperlukan untuk menyampaikan pengetahuan kepada para murid untuk mencapai tujuan pembelajaran. Maka dari itu, penelitian ini menyimpulkan bahwa bukan hanya kepribadian guru yang penting, namun kompetensi pedagogi juga sangat penting.
\end{abstract}

Kata kunci: Calon guru EFL; persepsi; guru Bahasa Inggris ideal; kompetensi guru 


\section{INTRODUCTION}

The importance of English is acknowledged by Indonesian government by putting it as a compulsory subject which resulting in the high demand of English teachers. The standards of being a professional teacher also have been set by the government in the Teachers Law Number 14, 2005. One of the requirements is having the four teacher competences namely pedagogical competence, personality competence, social competence, and professional competence. Despite the standards have been set since 2005, the empirical data shows disappointing facts.

According to articles published by Yunus (2017); Yunus (2018); Safutra (2018); and Jilan (2018) stated that the quality of education in Indonesia is below the standard. In addition, the result of Teachers Competence Test known as $U_{j i}$ Kompetensi Guru (UKG) in 2016 showed that the average score was only 44.5 which was below the standard of 55 . Other facts show that among 3.9 million teachers in Indonesia, $25 \%$ of them have not met required academic qualification and $52 \%$ of them have not had professional certification (Yunus, 2017). These situations become a concern because teachers' quality can highly influence student outcomes as well as education quality (Campbell, Kyriakides, Muijsc \& Robinsona, 2004; Siedentop \& Yinger, 2006; Rockoff, 2004 cited in Moradi \& Sabeti (2014).

In response, many researchers have done studies to improve teachers' quality. Some of them were focusing on improving the quality of English teacher. Brown and Rodgers (2002) cited in Wichadee (2009), stated that a good teacher in an EFL class requires a combination of a mechanical component and a mental component. The mechanical component refers to the skills required to present the content of the lesson in the most accessible ways for students, while the mental component includes teacher's belief system about teaching and learning as well as the teacher's personality.

Another research was conducted by Moradi \& Sabeti (2014). They tried to find out teachers' and students' perspectives of effective teaching from a closed-response format questionnaire. They categorized characteristics of effective EFL teacher into five categories, i.e., (1) content knowledge, (2) pedagogical knowledge, (3) communication skills, (4) managing skills, and (5) teaching experience. The results showed that pedagogical knowledge emerges as the most important. Meanwhile, teaching experience appears as the lowest priority.

The next previous study was conducted by Yulianto (2016). He attempted to describe a portrait of a professional EFL teacher based on the four teacher competence states in UU No. 14 Tabun 2005 namely pedagogical competence, personality competence, social competence and professional competence. He took one teacher who was considered as a professional teacher as his subject and tried to define his characteristics based on the four teacher competences. The result showed that the subject has fulfilled all of the four competences needed as a professional teacher.

Each of the previous studies has different aspects of characteristics of English teacher in teaching and learning. Study conducted by Yulianto (2016) only described one teacher which is considered as professional teacher. Thus, it cannot be used to generalize all teachers in Indonesia.

Curiosity of a concept of an ideal (EFL) teacher leads the researcher to find out EFL pre-service teachers' point of view related to an ideal English teacher in order to make language learning become successful by using four competence stated in Indonesian teacher's law no. 14 (2005) as the parameters. Therefore, EFL preservice teachers who are expected to be future English teachers need to know the importance of teacher competences as root for teachers in doing their professional 
duty which is educating students. Their perceptions of the criteria of an ideal English teacher within the framework of four teacher competences, and most important competence with the underlying reasons of choice were being studied. Thus, they can prepare themselves in terms of their skills, abilities, behaviors, and competences to meet the criteria of an ideal English teacher and improve the quality of education in the future.

\section{METHOD}

This study used an explanatory sequential mixed method where study is first done with a survey and then followed up with an interview. This method was chosen in hoping to give deeper explanation regarding to the finding in the quantitative study by doing an interview to some participants.

100 students of English Language Education batch 2016 which were on their seventh semester at Universitas Brawijaya participated. They were selected through a purposive sampling with criteria are having done Teaching Internship Program and having knowledge of teacher competences which had been taught on Teacher's Professional Ethics subject (Etika Profesi Pendidik). They filled out a questionnaire which is divided into two parts. The first part is 72 closed-ended statements of criteria of an ideal English teacher adapted from Moradi \& Sabeti (2014) questionnaire with five-point Likert scale. The items then were categorized into four teacher competences (i.e. pedagogical, personality, social, and professional) and represent the indicators of each competence explained in the PERMENDIKNAS No. 16 (2007) about standard of academic qualification and teacher competence. The second part is a question to choose one competence considered as the most important to be owned by teachers and an open-ended question to explain the underlying reason of the choice. Further, two males and two females were taken to be the interviewees to represent the sample who meet the trends found in this study which are those who put the highest mean score on the criteria related to the personality competence and chose pedagogical competence as the most important. The interview guideline consists of sixteen questions which were developed from the result found in the survey data. The questionnaire and interview guideline had been through the expert validation and the questionnaire had done a pilot testing.

After the data were gathered, the researcher analyzed them separately. For the quantitative data about the criteria of an ideal English teacher, the researcher used survey design data procession proposed by Ary, et. al (2010). This analysis includes four stages which are coding, statistical analysis, interpreting the results and reporting the findings. The statistical analysis was done by using SPSS 21 st version with descriptive analysis. Then the mean scores were categorized into five descriptive analysis criteria by Sugiyono (2010). While the reasons participants' consideration in choosing the most important competence, and the interview data were analyzed by following qualitative data analysis proposed by Miles, Huberman, \& Saldana (2014) which are data condensation, data display, and drawing and verifying conclusions.

\section{RESULTS AND DISCUSSION \\ EFL Pre-service Teachers' Perceptions of an Ideal English Teacher}

The participants responded to the 72 criteria of an ideal English teacher in the questionnaire which represents the four teacher competences. After the data has been analyzed, the mean score of each criterion were categorized according to the five descriptive analysis criteria by Sugiyono (2010).

It was found that, 28 out of 37 criteria that represent pedagogical competence were categorized as very high while, 9 criteria were categorized as high. In the personality competence criteria, 11 criteria were categorized as very high and 1 
criterion was categorized as high. For the criteria that represent social competence, 5 criteria were categorized as very high and 4 criteria were categorized as high. The last, 11 criteria on the professional competence were categorized as very high and 3 criteria belonged to high category.

The results reflected the very high and high frequency of the respondents who agree on criteria of an ideal English teacher presented in the questionnaire. Implicitly, the participants also agreed on the indicators of professional teacher set up by the Indonesian government which was explained further by the regulation of ministry of national education (PERMENDIKNAS) number 16 (2007) about standard of academic qualification and teacher competence because the items on the questionnaire represented the indicators of professional teacher competences since all of the items presented in the questionnaire are represent all of the indicators of teacher competences.

The overall mean score of items from each competence was rank from the highest to the lowest which is shown in the table 1.

\begin{tabular}{clc}
\multicolumn{2}{c}{ Table 1 Mean Scores of Each Competence } \\
\hline Rank & \multicolumn{1}{c}{ Competence } & $\begin{array}{c}\text { Mean } \\
\text { Score }\end{array}$ \\
\hline 1 & Personality Competence & 4.44 \\
2 & Professional Competence & 4.35 \\
3 & Pedagogical Competence & 4.34 \\
4 & Social Competence & 4.26 \\
\hline
\end{tabular}

EFL Pre-service Teachers' Perceptions of the Most Important Competence

A multiple-choice question which asks participants to choose the most important competence for teacher was presented in the questionnaire. The result is shown in table 2.

Table 2 Accumulation of the Most Important Competence

\begin{tabular}{clc}
\hline Rank & \multicolumn{1}{c}{ Competence } & $\mathrm{N}$ \\
\hline 1 & Pedagogical Competence & 37 \\
2 & Personality Competence & 34 \\
3 & Social Competence & 20 \\
4 & Professional Competence & 9 \\
\hline
\end{tabular}

The underlying reasons of each competence opted as most important were synthesized into its main reasons. It was found that:

Pedagogical competence was chosen as the most important competence by most respondents with eight main reasons. These eight points are (1) transferring or delivering knowledge is the main point of becoming a teacher, (2) pedagogical competence is basic of a teacher, (3) pedagogical competence deals with managing students' learning, (4) pedagogical competence deals with learning goals to be achieved, (5) it facilitates students to improve themselves, (6) it helps to improve students' motivation in learning, (7) it has a direct impact with the students, and (8) it covers the other three competences needed as a teacher.

Personality competence comes in the second rank as the most important competence an ideal teacher should have. The researcher found five main reasons of underlying the choice. Those five reasons are (1) the teacher itself needs to have 
good personality or their self-branding, (2) teacher is a role model or an example for their students, (3) teacher must respect and be respected, (4) build confidence and comfort, and (5) personality competence effects other competences too.

Social competence ranks third as the most important competence. After being summed up, twenty people chose this competence as the most important competence because of (1) teacher needs to have a good social ability, (2) teacher needs to have a good communication skill, (3) social competence makes teacher be more open-minded with their surroundings. It also involves teachers to be engaged with all students which make a good relationship between them.

The least chosen competence is professional competence. It was only chosen by 9 out of 100 respondents who participated on this study. The participants chose this competence because of three main reasons. They are (1) professional competence makes teacher reflect to themselves, (2) requires teacher to master the subject matter, and (3) it makes teacher has his/her own style in teaching.

\section{EFL Pre-service Teachers' Perceptions of the Divergence Finding}

The difference finding on overall rank between competence in criteria of an ideal English teacher and competence opted as most important meaning that the finding of this study is divergence or disconfirm each other. Therefore, the interview was done to uncover more information pertinent to the divergence finding in this study. The informants' knowledge and opinion about teacher competence, Indonesian teachers' quality and competences, the contribution of teacher competences in teaching, and Indonesian education are also explored. The information provides more rationale of the research topic which is teachers' professional development and Indonesian education quality.

\section{Knowledge and opinion about teacher competence}

The researcher asked the interviewees understanding of teacher competences. They defined teacher competence as skills or abilities that should be owned by teachers in educating their students. Other than that, they have clear definition of each teacher competence. First, they defined pedagogical competence as teachers' ability on managing students' learning, how teacher deliver or re-teach the knowledge or material that they have gotten. Second, personality competence is defined as teachers' good individual personality that should be a role model and example for their students. For the social competence, they describe it as teachers' social ability as a human being such as how to communicate and interact with people especially students, colleagues, and other school components. The last, professional competence is understood as the way teacher is professional on their job as a "teacher" such as having a broad knowledge, enhancing individual abilities, etc. They got the information about teacher competence from many sources ranging from books and the internet to lectures at some subjects because they major in education.

\section{Indonesian teachers' quality and competences}

The interviewees' opinion about Indonesian teachers' quality and competence is similar. They stated that Indonesian teachers' quality is good, but it still needs to be improved. Many of Indonesian teachers do not have a willingness to improve. With the globalization and the development of technology, teachers should keep in pace with the change of era and keep up with the development and trends, especially in using technology and newest teaching methods. Then, they regret that lot of Indonesian teachers who teach English subject that still use Bahasa Indonesia as the instructional language. They believe 
that English is an applicable skill where students will get accustomed with English if they use it a lot. It will make them get more experiences and practices in using English. This opportunity only occurs inside English class since they live in an EFL country where English only being learnt and not be used in daily communication. So, if English teachers use Bahasa Indonesia as the instructional language, students will lose their opportunity to practice and learn more. It is one of the reasons that Indonesian students do not have big improvement in English learning.

For the competences of teacher in Indonesia, the interviewees perceived that Indonesian teachers have tried to own the four teacher competences required in teaching. Yet, some of the competences are still in need of an improvement especially on the pedagogical competence and personality competence. In pedagogical competence, they hoped that Indonesian teachers are more creative in teaching and better in managing the class because teachers need to be able to deliver the materials to all of students in the class and make sure that the materials are well received and being understood by all of them. As for the personality competence, the interviewees believed that the teachers have tried to show good side of them in front of their students. Yet, many of them still have not showed a good example even when they are still in the school area. The respondents hoped that teachers always do their best to establish good example not only in front of students, but also when they are still in the school area. In the social and professional competence, the interviewees argued that teachers' quality on those two competences is good enough.

\section{Divergence Finding}

The criteria on personality competence got the highest mean score out of the four teacher competences. The interviewees gave big impacts on this result because they chose strongly agree to all of the criteria which represented the personality competence. On the interview, they explained the reason of their choice is because they believe that teachers are a role model who have to set good example for their students. That is why teachers need to have a good personality and be considerate with everything they do. Moreover, teachers who have good personality will be loved by their students. When it happens, eventually the students will be more interested in learning the subject taught by the teachers.

Furthermore, the reasons they chose pedagogical competence as the most important competence are similar to the respondents' answer on the questionnaire. They emphasized that teaching is the main task of being a teacher where they have to deliver their knowledge to their students to achieve the learning goals. They explained that having a good personality competence, much knowledge, and good social skills will not make them a teacher if they could not manage the learning process as it means they cannot deliver the material to their students since the main reasons of students entering a school are they want to gain knowledge and experience. The knowledge will be well received when teachers have good pedagogical competence. Moreover, having fun, friends, building personality are just other benefits that students will get during the learning process. Yet, still, the students' main purpose of entering school is getting the material.

Despite the highest mean score for personality competence and the selection of pedagogical competence as the most important competence, the interviewees believed that all the four teacher competences were needed and contribute to the concept of an ideal English teacher. They stated that the four teacher competences were the foundation of an ideal English teacher. All teachers must try to have the four teacher competences. They do not need to be good and cover all of the indicators, but they must try to be perfect for their students. 


\section{Contribution of teacher competences in teaching}

When it comes to teaching, all of the competences make contribution. They are working together at the same time. First, before teaching, teachers should master the material which will be taught. Teachers also need to enhance their ability in teaching, be creative, keep up with technology, and be update with newest information and trends to create an interesting lesson which is suitable with students' characteristics. This is the contribution of their professional competence. Then, they need to prepare and deliver the material through their pedagogical competence. In the process of teaching, all of competences contribute. Teacher should transfer the material that they have mastered in their professional competence to the students. They will show their pedagogical competence by managing the class, making sure that the knowledge that they deliver is received and understood by all of the students. In the process of delivering, they will use their social competence such as how to adapt, communicate and interact with variety of students. They also need to show their personality competence too in how they handling their students, speak and behave politely, and act professionally as a teacher. Moreover, all of the teacher competences are not only need to be implemented in class, but also when teachers are still in the school area. Teachers need to do their job and act professionally as a teacher.

\section{Indonesian education}

All of the interviewees agreed that all of teachers should possess and understand the four teacher competences. They believed that teacher competences will give a good impact not only on education, but also on the development of a country since teachers' competencies give big influence on students' achievements. Students themselves are the future successor to the nation. So, if teachers can produce qualified students, it means that they also produce a qualified people for the future of this country.

Moreover, all of the interviewees agreed that Indonesian education has shown an improvement if they compare it with the past. The education has developed slowly on many things. Yet, in order to make a better education, there are some things that needs to be changed, improved and developed on Indonesian education. There were some suggestions that the interviewees gave to improve the education in Indonesia.

The first suggestion is the difficulty of lessons' material. One of the interviewees stated that the change of curriculum to 2013 curriculum gave difficulties to students and teachers. There are some materials that should be taught on higher grade, but it is already taught to early grade students which make it harder for them to understand the material. Therefore, teachers should find a way to deliver the material in the most accessible way for students so that it is easier for them. The interviewee suggested developing a curriculum by adjusting with students' grade and arranging the material in stages from the basic to the difficult one.

The second is school duration. Indonesian school period consists of twelve years from elementary until senior high school. One of the interviewees said that if she compared it with her friends from abroad, many of them who are on her age already have a good job, got a good degree such as master or Ph.D., etc. It is because their countries' school period is shorter than Indonesia's. So, the interviewee suggested decreasing school duration.

The third suggestion is putting more practical lessons to develop students' soft skills. The interviewees believe that real-life practices and soft skills are more needed in the real life's application. After twelve years of studying at school and additional four years in the college, many 
students are still not ready to face the real life. Many of them are still unemployed because they do not have skills that are required in at work. Those twelve plus four years of studying are like a waste of time because many of them cannot even get a job that they wanted. So, it is better to teach them more applicable skills that will be needed in the company and will help them after finishing or graduating from their study such as public speaking, accounting, etc.

The last suggestion is improving the teachers' welfare. One of the interviewees said that the importance of teachers' role on the future of the country does not commensurate with what they get in return. Many Indonesian teachers do not have enough salary especially those who teach on the remote area. It will be better if the government can guarantee the teachers' welfare. It can make teacher be more motivated and responsible in running their professional duty which is educating students who are the successor of the nation.

\section{CONCLUSION}

This study was trying to find out the EFL pre-service teachers' perception about an ideal English teacher by considering their perception about; 1) the criteria of an ideal English teacher based on the four teacher competences and 2) the most important competence and its underlying reasons of the four teacher competences. The result found that the EFL pre-service teachers were mostly agreed on the criteria of an ideal English teacher within the framework of four teacher competences. It was shown from the very high and high mean score category of mean score in each criterion. The overall mean score on each competence showed that personality competence got the highest. Further, all of the competences were chosen as the most important in different votes with pedagogical competence opted the most. The reasons were varied from pedagogical competence dealt with transferring knowledge as teachers' task to pedagogical competence covered other three competences as well.

The different result on the competence who got the highest mean score and considered as the most important had led the researcher to dig more information about this finding by interviewing some participants. The interviewees agreed with the items on the personality competence as teachers are role model who must set good example for their students. Yet, they emphasized that students' main reason of entering school is to get knowledge and experience. Therefore, teaching becomes teachers' main task where they need to deliver their knowledge to their students in order to achieve the learning goals and to make students get what they wanted from school.

These results showed kind of English teacher that EFL pre-service teachers' desire considering their experience of being a student and teacher, gotten from the teaching internship program. Moreover, it also shows what kind of teacher that they are going to be in the future. The high frequency of agreement in the criteria of an ideal English teacher means that a portrait of an ideal English teacher in their mind has been described by Indonesian government in detail in the Teachers Law number 14 (2005) and PERMENDIKNAS No. 16 (2007). However, it might be hard for teachers to cover all of the criteria on each competence. Therefore, with the discovery of the competence that considered as most crucial, pedagogical and personality competence, teachers can be more focused on enhancing their skills on those two competences. Yet, it does not mean that social and professional competences are being left out because those two competences also contribute in teaching.

Related to the research topic which is teachers' professional development and Indonesian education quality, the interviewees believed that most of Indonesian teachers have tried their best to own the four teacher competences and 
cover all of the indicators on each competence especially young teachers who are more adaptable with students' characteristics on this era. The interview also showed that the interviewees believed Indonesian education has moved to a better quality. Yet, it still needs to be improved on many aspects which is shown from the suggestions on Indonesian education which was given by the interviewees.

\section{ACKNOWLEDGEMENTS}

Our deepest gratitude goes for English Language Education Program Faculty of Cultural Studies Universitas Brawijaya for all the support and facilities that made this reseach accomplished.

\section{REFERENCES}

Brown, J., \& Rodgers, T. (2002). Doing second language research. Oxford: Oxford University Press.

Campbell, R. J., Kyriakides, L., Muijsc, R. D. \& Robinsona, W. (2004). Effective teaching and values: Some implications for research and teacher appraisal. Oxford Review of Education, 30(4), 451 - 465.

Jilan, B. (2018, September 1). Permasalaban Guru di Indonesia. Universitas Islam Negri Jakarta. Retrieved from https://www.uinjkt.ac.id/id/perm asalahan-guru-di-indonesia/

Moradi, K., \& Sabeti, G. (2014). A Comparison of EFL Teacherss and EFL Students' Understandings of 'Highly Effective Teaching'. International Conference on Current Trends in ELT. Procedia - Social and Behavioral Sciences 98 (2014) p. 1204 - 1213. Elsevier Ltd. Retrieved from https://www.sciencedirect.com/sc
ience/article/pii/S1877042814026 263

Peraturan Pemerintah No. 32 (2013) Tentang Perubahan Atas Peraturan Pemerintah No. 19 (2005) Tentang Standar Nasional Pendidikan

Rockoff, J. E. (2004). The impact of individual teachers on student achievement: Evidence from panel data. The American Economic Review, 94(2), 247-252.

Safutra, I. (2018, November 26). Kompetensi Guru Dibawah Standar, IGI: Hasilnya Siswa Masib Tertinggal. Jawa Pos. Retrieved from https://www.jawapos.com/feature s/humaniora/26/11/2018/kompet ensi-guru-di-bawah-standar-igihasilnya-siswa-masih-tertinggal/

Siedentop, D. \& Yinger, R. (2006). A systemic approach to enhancing teacher quality: The Ohio model. Journal of Teachers Education, 57(1), 1321.

Undang-Undang Republik Indonesia Nomor 14 (2005) Tentang Guru dan Dosen

Wichadee, S. (2010). Defining the Effective English Language Teacher: Students' and Teachers' Perspectives. Bangkok University International Studies. In A. M. Stoke (Ed.), JALT 2009 Conference Proceedings. Tokyo: JALT. Retrieved from http://jaltpublications.org/archive/proceedi ngs/2009/E033.pdf

Yulianto, H. (2016). A Portrait of Professional English Teacher. (Unpublished Thesis). Universitas Brawijaya, Malang, Indonesia. 
Yunus, S. (2017, November 24). Yunus, S. (2018, November 26). Mengkritisasi Kompetensi Guru. Mengkritisasi Kualitas Guru. Media Detik.com. Retrieved from Indonesia. Retrieved from https://news.detik.com/kolom/dhttps://mediaindonesia.com/read 3741162/mengkritisi-kompetensiguru /detail/200182-mengkritisikualitas-guru 